\title{
ГЕОГРАФИЯ
}

УДК 911.52 (470.44)

\section{ЛЫСОГОРСКОЕ ПЛАТО КАК ЛОКАЛЬНАЯ МОДЕЛЬ ЛАНДШАФТОВ ЮЖНОЙ ЛЕСОСТЕПИ САРАТОВСКОЙ ОБЛАСТИ}

\section{Г.П. Бобров, Л.А. Тархова}

Саратовский государственный университет, кафедра физической географии и ландшафтной экологии E-mail: gis@sgu.ru

В статье речь идет о проблемах структурно-динамического направления ландшафтоведения. При помощи геофизических и биогеофизических показателей дается оценка ландшафтной структуры региона на примере лесного массива, являющегося природным парком «Кумысная поляна». Лысогорское плато в окрестностях г. Саратова рассматривается как малая локальная ландшафтная модель южной лесостепи Саратовской области. Отражена взаимосвязь вышеназванных показателей и подчеркнута их репрезентативность в оценке пригодности территории в целях эколого-рекреационного природопользования.

Ключевые слова: геофизические и биогеофизические показатели, ландшафтная структура, Лысогорское плато.

\section{Lysogorsky Plateau as Local Model of Landscapes of Southern Forest-Steppe of the Saratov Region}

\section{G.P. Bobrov, L.A. Tarkhova}

The question is problem of the structurally-dynamical school in landscape science. The estimation of region landscape structure is resulted on the example of the forest area in natural park «Kumysnaya polyana» by means of geophysical and biogeophysical indicators. The Lysogorsky plateau near Saratov-city is considered as a small local landscape model of southern forest-steppe of the Saratov region. The interrelation of above-named indicators is reflected and emphasized their representativeness in an estimation of territorial suitability for the purpose of ecological and recreational land-use management.

Key words: geophysical and biogeophysical indicators, landscape structure, Lysogorsky plateau.

Постановка проблемы. Экологическую, рекреационную, противоэрозионную, водосберегающую, кислородопоставляющую и очистительную роль лесных массивов Лысогорского плато в окрестностях Саратова трудно переоценить. Для сравнения: в городской черте Саратова около 300 га зеленых насаждений общего пользования, а природный парк «Кумысная поляна» имеет около 3500 га. Один гектар насаждений поглощает за час 8 кг углекислоты, которую выделяют за то же время 200 человек; каждый гектар леса переводит 1700 м $^{3}$ воды поверхностного стока в грунтовый, полностью прекращаются размывы в прилегающих оврагах; лес выделяет значительное количество фитонцидов - от 450 до 60 кг/га в зависимости от породы деревьев; средняя пылепоглотительная способность леса в пределах 3-4 т/га; кислородопродуктивность до 4 т/га [1].

Однако разнообразие ландшафтных условий, антропогенная нагрузка на лесные массивы плато, расположенного в черте города, приводят к различиям в состоянии его основных гео- и биогеофизических показателей.

Работы, выполняемые в рамках структурно-динамического направления ландшафтоведения по исследованию гео- и биогефизических характеристик ландшафтов и оценке их экологической значимости, в настоящее время не редки. Но значительная часть таких работ проводит-
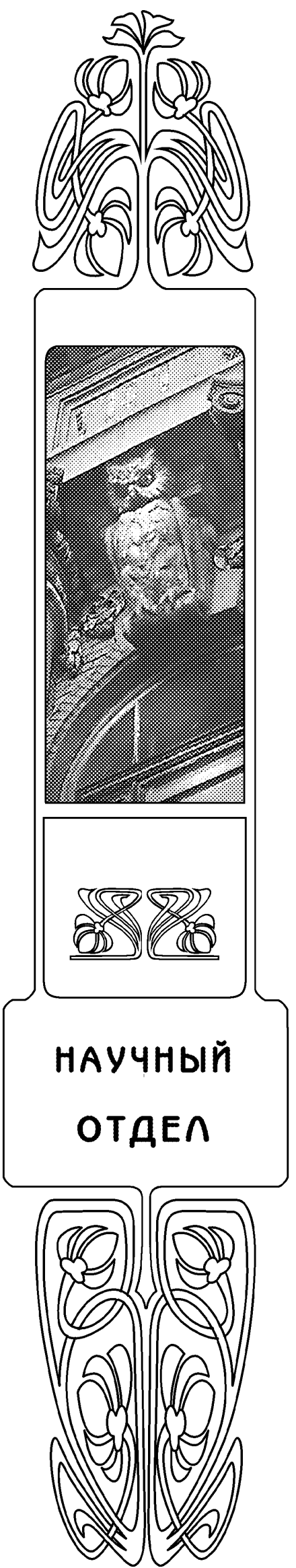
ся на региональном ландшафтно-географическом уровне, как правило, по материалам сетевых метеостанций. В силу этого не всегда освещается природный режим отдельных ландшафтных районов локального ранга.

Цель исследований заключалась в выявлении особенностей распределения гео- и биогеофизических показателей по элементам ландшафта, представленным на локальном уровне.

Объектом исследования служила территория природного парка «Кумысная поляна», включающая Лысогорское плато (с крутым денудационным уступом и элементами эрозионного расчленения), которое отражает природные особенности южной лесостепи Саратовской области и может служить малой локальной ландшафтной моделью.

Методы исследования включали полевые натурные наблюдения с использованием трансектного метода, комплексного описания на основных ключевых участках, использовались расчетные методы и данные лесотаксационных описаний.

Оценка гео- и биогеофизических показателей ландшафтной структуры базировалась в первую очередь на выявлении двух основных факторов дифференциации ландшафтных условий - крутизне и экспозиции склонов, четко прослеживающихся и представленных широким спектром. С учетом этих показателей при анализе отраслевых карт была выявлена ландшафтная структура природного парка.

Ландшафтное районирование природного парка «Кумысная поляна» представлено тремя природными местностями: водораздельным пространством, крутым денудационным уступом, урочищами эрозионной сети, которые глубоко врезаны не только в поверхность уступа, но местами и в водораздельную поверхность. Местности включают 31 вид урочищ - от крупных (сотни гектаров) до мелких (менее одного гектара) (рис. 1).

Рисунок ландшафта характеризовался коэффициентом расчленения А.С. Викторова [2] и определялся как отношение длины ландшафтных контуров к их площади. Наиболее однородны водораздельные поверхности (коэффициент расчлененности $0,019 \mathrm{M}^{-1}$ ), более расчленены природно-территориальные комплексы (ПТК) крутого денудационного уступа $\left(0,028 \mathrm{~m}^{-1}\right)$, максимально расчленены урочища эрозионной сети $\left(0,045 \mathrm{M}^{-1}\right)$.

Геосистемы плато отличаются не только морфометрическими параметрами (крутизна, экспозиция), литогенной основой, но и почвенным и растительным покровом. Каждому виду урочища присущ определенный набор геофизических показателей, основными из которых являются: приход солнечной радиации к подстилающей поверхности, радиационный баланс, величина фотосинтетически активной радиации, суммы температур почвы и воздуха, осадки, влагозапасы почвы, величина испарения и испаряемости, высота снежного покрова и др. На эти различия, с учетом с антропогенной нагрузки, в первую очередь реагирует травянистая растительность, затем и древесные ценозы.

Анализ основных гео- и биогеофизических показателей. Основные гео- и биогеофизические показатели отдельных элементов ландшафтной структуры (плакорных участков, склонов уступа плато северной и южной экспозиции, урочищ эрозионной сети) сведены в табл. 1. Для сравнения приводятся фоновые данные метеостанции Саратов «Юго-Восток» (гипсометрическая отметка 120 м) (см. табл. 1).

При анализе табл. 1 выявлено, что склоны денудационного уступа Лысогорского плато южной ориентации имеют критические ландшафтные показатели для наших региональных условий. Это выражается в следующем:

- повышенном радиационном балансе при малом увлажнении;

- малой величине испарения при значительной испаряемости, поэтому отношение $E / E_{0}$ мало;

- меньшей высоте снега, малых показателях снежности;

- большой величине радиационного индекса сухости Будыко;

- суммарная ФАР высока, а КПД ФАР низкий за счет небольшой продуктивности фитомассы.

Исследуя связь особенностей лесных массивов Лысогорского плато, мы использовали данные лесотаксационных обследований (1995 г.), соотнесенные с ландшафтной структурой территории. Для этого на ландшафтную основу была наложена схема расположения лесных кварталов с выделами. По таксационным данным и показателям ландшафтной структуры были построены ряд карт с характеристиками лесов, густотой дорожно-тропинчатой сети, а также вертикальные профили ландшафтной структуры природного парка и проанализированы данные лесотаксационных таблиц.

Анализ карт распределения средних характеристик лесных массивов показал, что наибольшее присутствие открытых участков среди лесных массивов наблюдается в восточной части склонов (до 90\%) и на юго-восточных склонах плато (до 50-70\%). Наименьшая часть открытых участков (ландшафтных полян) обнаруживается в центральной части водораздельного пространства, западнее и северо-западнее большой Кумысной поляны, в северной и западной частях парка (менее $5 \%$ ). К этим местоположениям примыкают кварталы, в которых доля полян составляет до $30 \%$. Основная часть парка имеет полноту леса в пределах 0,6-0,7, отдельные северные и северовосточные кварталы составляет лес с полнотой 0,7-0,8, на восточных, юго-восточных склонах полнота в среднем не превышает 0,6 . Южный сектор парка имеет полноту менее 0,4.

Распределение среднего возраста деревьев по территории Кумысной поляны очень мозаич- 


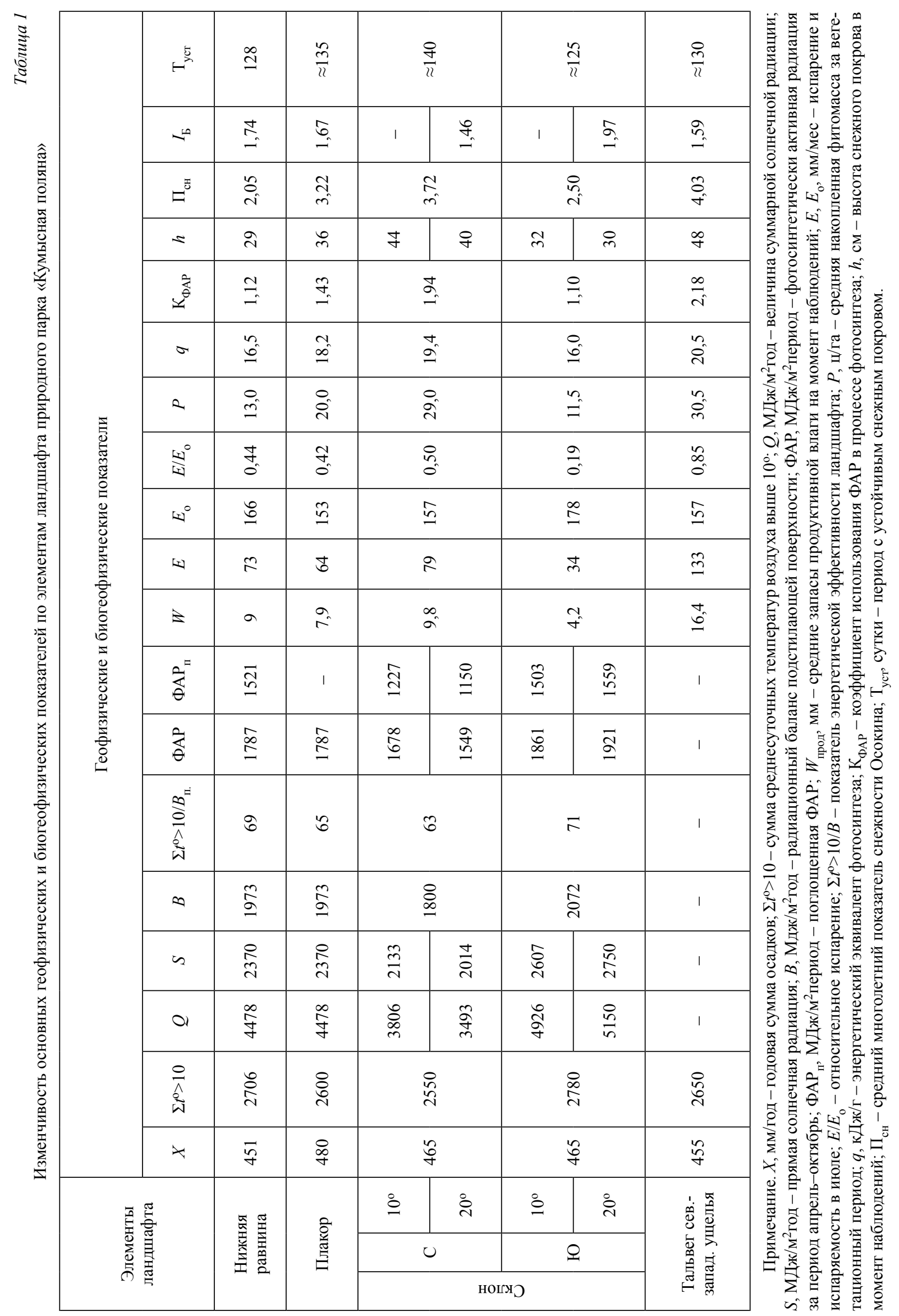




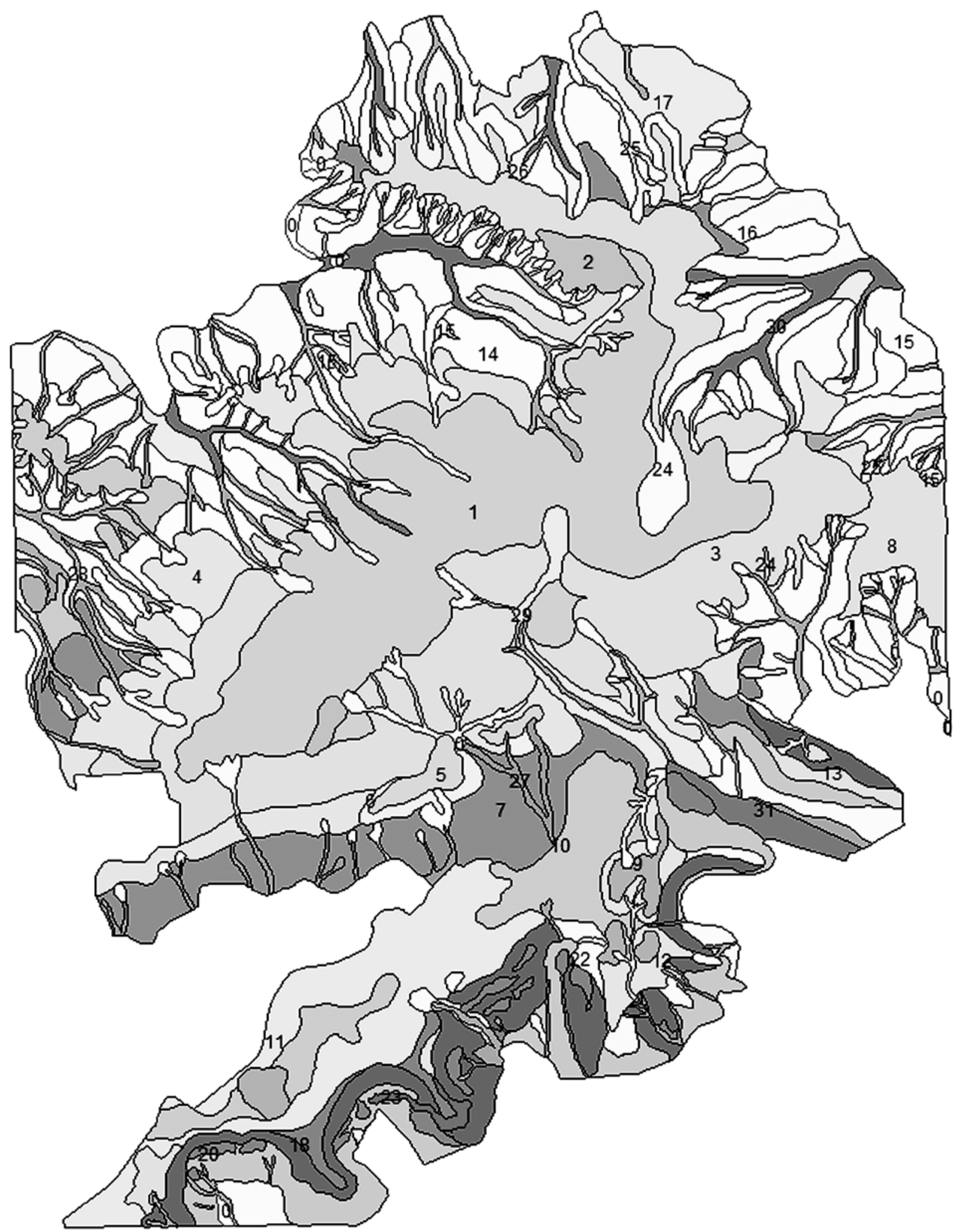

Рис. 1. Ландшафтная карта-схема природного парка «Кумысная поляна». Масштаб $1: 40000$ :

ПТК водораздельных пространств: 1 - плоские ровные поверхности (290-295 м) крутизной 0-2 со слаборазвитым элювиальным чехлом на песках и песчаниках саратовского яруса палеогена с серыми лесными песчаными и супесчаными почвами под липо-дубравами, березняками, осинниками и преимущественно черноземами выщелоченными суглинистыми и супесчаными с разнотравно-злаковыми ассоциациями на полянах и рединах; 2 - слабовыпуклые и плосковершинные повышения (290-295 м) крутизной 0-4 с элювиальным чехлом на песках саратовского яруса палеогена с серыми лесными легкосуглинистыми и супесчаными почвами под дубово-кленовниками, осинниками и посадками сосны; 3 - слабонаклон- 
ные ровные поверхности водоразделов (275-290 м) крутизной 0-5 с элювиально-делювиальным суглинистым чехлом на песках саратовского яруса палеогена с серыми лесными песчаными и супесчаными почвами, черноземами выщелоченными, преимущественно под кленово-липо-дубравой; 4- очень пологие и пологие поверхности (265-285 м) крутизной 1-8 c элювиально-делювиальным чехлом на песках и песчаниках саратовского яруса палеогена с темно-серыми лесными суглинистыми и тяжелосуглинистыми почвами и черноземами выщелоченными тяжелосуглинистыми под дубово-липовыми лесами и мезофильно-разнотравными полянами; 5 - выпуклые вершинные бугристые поверхности повышений (280 м) крутизной 0-2 ${ }^{\circ}$ с элювиальным чехлом преимущественно песков и песчаников саратовского яруса палеогена с темносерыми и серыми лесными суглинистыми и супесчаными почвами под посадками сосен и дубово-кленовыми ассоциациями; 6 - очень пологие и пологие склоны повышений (275 м) крутизной 1-8 с элювиально-делювиальным чехлом на песках и песчаниках саратовского яруса палеогена с темно-серыми и серыми лесными суглинистыми и супесчаными почвами преимущественно под липово-дубравами; 7 - полого и покато-наклонные, местами расчлененные межбалочные склоны (260-270 м) крутизной 1-8 с серыми и темно-серыми лесными суглинистыми и супесчаными почвами на суглинистом делювии под садами, а также участками древесной растительности, представленной куртинами дуба, липы и мезофильных лугов; 8 - бугристые поверхности на высотных уровнях (240 и 280 м) крутизной $0-5^{\circ}$ с древнеэоловой переработкой песков и опок палеогена, использованные под карьеры по добыче песка и щебня опок, с участием в травянистом покрове разнотравноксеро- и мезофильной растительности; 9- выпуклые вершины денудационных останцов (235-265 м) крутизной $5-10^{\circ}$, сложенные песками и песчаниками сызранского яруса палеогена с эродированными песчаными и супесчаными черноземами и серыми лесными почвами под степной растительностью: типчаково-ковыльной с участием полыней, песколюбов; кустарниками, а также посадками сосен; 10 - слабоволнистая поверхность склонов останцов (240-265 м) крутизной 0-8 с темно-серыми лесными почвами под дубово-вязовыми лесами; 11 - полого наклонные денудационные поверхности до $2^{\circ}$ (240-255 м), выработанные в песках сызранского яруса палеогена, с темно-серыми супесчаными и легкосуглинистыми почвами под ландышевой липово-дубравой с господством осины на вырубках и злаково-разнотравной луговой степью с обилием осок на черноземах выщелоченных тяжелосуглинистых; 12 - покатые (3-10), преимущественно присетьевые склоны поверхности (230-280 м), представленные мезофильной травянистой растительностью на черноземовидных почвах, сформированные на опоках сызранского яруса палеогена; 13 - полого- и покато-сглаженные (3-12 ${ }^{\circ}$ денудационные гребневые поверхности, узкие межсетьевые пространства (мысы) $(165,265$ м) с щебнем песчаника и опок сызранского яруса палеогена с эродированными песчаными и супесчаными черноземами с высокой степенью проективного покрытия типчаково-ковыльной растительности и дубово-вязовыми лесными участками; ПТК крутого денудационного уступа: 14 - выпуклые мысообразные межсетьевые слабопокатые, покатые денудационные склоны (235-285 м) крутизной 5-15인 с щебнем верхнемеловых опок и глин; 15 - выпуклые пологие и сильно покатые эрозионные $\left(5-20^{\circ}\right)$ склоны сложного профиля (200-215 м) с серыми лесными среднесмытыми суглинистыми почвами под липово-дубравой; 16 - крутые эрозионные (до 20) склоны (190-280 м), с серыми лесными слаборазвитыми, эродированными почвами на делювиальных суглинках и супесях с примесью дресвы и щебня, представленные дубово-кленово-липовыми лесами с примесью осины и березы; 17 - слабопокатые (3-10²) террасовидные склоны (150-250 м) с серыми лесными неполноразвитыми суглинистыми почвами на делювиальных суглинках, представленные липо-дубравой с примесью клена, осины, березы; 18 - крутые $\left(15-20^{\circ}\right)$ оплывно-оползневые склоновые поверхности эрозионных цирков (от 170-230 до 220-260 м) с уклонами до 45 с маломощным суглинисто-щебнистым делювием на верхнемеловых и палеогеновых опоках и песчаниках (нередко обнаженных) со слабо развитыми и сильносмытыми черноземовидными почвами, осыпями с ксерофитной полынно-злаковой, разреженной кустарниковой, дубраво-ясенево-вязовой растительностью; 19 - выпуклые бугристые поверхности крупных оползневых тел от 6-8 $8^{\circ}$ до $25-30^{\circ}$ на коллювиальных отложениях коренных меловых и палеогеновых опок и песчаников с черноземовидными маломощными почвами с мезофильно-ксерофильным разнотравьем и степными кустарниками; 20 - оползневые склоны сложного профиля: бугристые, террасовидные, крутые и покатые $\left(10-15^{\circ}\right)$, развитые на нижней и средней третях склонов эрозионных цирков на абсолютных отметках от 160 до 220 м на верхнемеловых и палеогеновых опоках, представленные вязово-ясенево-дубовыми участками леса, степными кустарниками и ксеро-мезофильным разнотравьем на южных неполноразвитых, черноземах; 21 - вогнутые оплывно-оползневые ступенчато-террасовидные склоны днищ цирков (160-190 м) крутизной 10-15 с черноземами обыкновенными на пролювиально-делювиальных отложениях, с преобладанием суглинков, а также глин, супеси с дресвой и щебнем, представленные мезофильным лугом, степными кустарниками, кленово-яенево-дубовыми участками леса; 22 - выпуклые покатые (190-250 м) мысообразные оплывнооползневые склоны - увалы $\left(10-15^{\circ}\right)$, представленные черноземами обыкновенными слабосмытыми на делювиальных суглинках, опоках и песчаниках дочетвертичного происхождения, со злаково-полынно-степной растительностью; 23 - крутые уступы, обрывы, стенки срывов $\left(25^{\circ}\right)$, локально распространенные на высоте 210 м, коллювиально-осыпные и обвальные отложения на меловых и палеогеновых материнских породах, при отсутствии почвообразовательных процессов, лишенные растительности; Урочища эрозионной сети: 24 - лощинообразные и западинообразные элювиально-делювиальные водосборные понижения на водораздельных равнинах (250-290 м) крутизной от 1 до $5^{\circ}$ с серыми лесными почвами под кленово-липово-дубравой; 25 - лоткообразные и лощинообразные элювиально-коллювиальные комплексы понижений на склонах денудационного уступа (150-280 м); 26 - западинообразные элювиальные понижения на склонах денудационного уступа (240-285 м) с намытыми почвами; 27 - потяжины и лощины (265-275 м) делювиально-пролювиальные, представленные глинистыми, суглинистыми, супесчаными с дресвой и щебнем с эродированными почвами; 28 -лощины и балки, реже овраги аллювиально-коллювиального происхождения (175-285 м) крутизной от 5 до $20^{\circ}$, заиленные мелкоземом, намытыми почвами с пышно развитой древесно-кустарниковой и травянистой растительностью; 29 - покатые склоны балок (240-285 м) пролювиально-делювиального происхождения с суглинистыми, глинистыми почвами с щебнем и дресвой крутизной 5-15 с серыми лесными неполноразвитыми и черноземными неполноразвитыми; 30 - днища ручьев и балок (200-215 м) с пролювиально-аллювиальными суглинками и песками с галькой и гравием, намытыми почвами; 31 - террасы долин мелких речек (165 м), представленные аллювиальными суглинками, супесями, песками с галькой, с оставшимися фрагментами дерново-намытых почв с кленово-липово-дубравой, в большей степени лишенной естественной растительности в связи застройкой. 
но. Юго-восточный и восточный сектора парка представлены в основном лесом в возрасте до 60 лет. Средний возраст дуба по территории парка составил 61 год, наиболее старым оказался клен - 63 года, средний возраст липы 58 лет и самым молодым является ясень - 35 лет. Старый лес (возраст 80-90 лет) имеется фрагментарно в центральной, северной и западной частях парка, на пяти выделах возраст дуба превышает 100 лет. Самый молодой лес растет на склонах южных экспозиций (40-50 лет), что, видимо, связано с посадками 50-60-х гг. минувшего столетия. Наиболее старые деревья встречаются на плакоре (средний возраст дуба 72 года, липы 56 лет), а также на северных и северо-западных склонах (в среднем 60-65 лет).

Распределение объемов сырорастущей древесины $\left(\mathrm{M}^{3} /\right.$ га) также указывает на структуру и состояние лесных фитоценозов. Наибольшие запасы сырорастущей древесины наблюдаются в центральной части плато, где средний объем древесины составляет от 140 до $170 \mathrm{~m}^{3} /$ га и более. Минимальные запасы древесины в восточном и юго-восточном секторе парка 80-50 м³/га и менее. Наибольшую продуктивность имеет липа: выделы, в которых преобладает липа (70\% и более), средний запас древесины составил $182 \mathrm{~m}^{3} /$ га, затем следует клен $\left(129 \mathrm{~m}^{3} /\right.$ га). Средние объемы древесины с преобладанием липы на северных и северо-западных склонах составляют 190-200 м³/га, на некоторых выделах - до $280 \mathrm{~m}^{3} /$ га. Выделы с преобладанием дуба также имеют наибольшие запасы древесины на плакоре и северо-западных склонах, но всего в пределах 130-140 м³/га.

В недалеком прошлом южные пространства лесостепи были в основном заняты чистыми дубравами, но хозяйственная деятельность (особенно в период Великой Отечественной войны) привела к значительной вырубке леса. По данным T.М. Трифоновой [1], сейчас сохранилось 50\% насаждений, но и они подвергаются механическим повреждениям при строительстве коллективных гаражей, жилых домов, сваливании мусора. В настоящее время наибольшей сохранностью обладают культуры в возрасте 13-20 лет (дуб, вяз, ясень, клен, лещина, лох узколистный). Основные дубравы все более заменяются липой и кленом, которые растут более интенсивно в молодом возрасте и размножаются как порослью, так и семенами. Дуб черешчатый на Лысогорском плато практически имеет порослевое происхождение, семенной дуб размножен посадками и занимает незначительную площадь.

Более четкая картина характеристик леса выявляется при рассмотрении таксационных характеристик в зависимости от экспозиции склонов (табл. 2).

Таблица 2

Средние параметры древостоев доминирующих пород на плакоре и склонах Лысогорского плато

\begin{tabular}{|c|c|c|c|c|c|c|c|c|c|}
\hline \multirow{2}{*}{ Элементы рельефа } & \multirow{2}{*}{$\begin{array}{l}\text { Центральная } \\
\text { часть плакора }\end{array}$} & \multicolumn{8}{|c|}{ Склоны Лысогорского плато } \\
\hline & & $\mathrm{C}$ & $\mathrm{CB}$ & B & ЮB & Ю & Ю3 & 3 & $\mathrm{C} 3$ \\
\hline \multicolumn{10}{|c|}{ Дуб } \\
\hline Число выделов & 86 & 36 & 13 & 16 & 28 & 18 & 7 & 11 & 10 \\
\hline Возраст, лет & 71,8 & 62,5 & 58,5 & 51,6 & 49,1 & 44,9 & 52,8 & 63,6 & 63,0 \\
\hline Высота, м & 15,5 & 13,0 & 13,9 & 12,9 & 11,2 & 9,3 & 12,8 & 15,1 & 15,5 \\
\hline Диаметр, см & 24 & 20 & 21 & 18 & 19 & 17 & 23 & 22 & 22 \\
\hline Запас древесины, м³/га & 134 & 119 & 120 & 115 & 2 & 60 & 101 & 141 & 139 \\
\hline \multicolumn{10}{|c|}{ Липа } \\
\hline Число выделов & 25 & 33 & 15 & 7 & 2 & 2 & 8 & 6 & 5 \\
\hline Возраст, лет & 56,5 & 63,4 & 55,7 & 45,7 & 45,0 & 40,0 & 52,5 & 57,5 & 61,0 \\
\hline Высота, м & 17,1 & 17,4 & 16,0 & 14,1 & 14,0 & 13,0 & 15,8 & 17,5 & 18,4 \\
\hline Диаметр, см & 20 & 18 & 18 & 16 & 17 & 16 & 20 & 21 & 21 \\
\hline Запас древесины, м³/га & 180 & 194 & 187 & 143 & 150 & 140 & 159 & 182 & 202 \\
\hline
\end{tabular}

Анализ табл. 2 показывает на четкую дифференциацию таксационных параметров по породам и местоположению. Критические показатели (возраст, высота и диаметр деревьев, запас древесины) наблюдаются на склонах южных экспозиций. Это связано с большим значением радиационного индекса сухости $\left(I_{Б}\right)$, со значительной испаряемостью и одновременно с малыми влагозапасами. Для Саратова избыточныий приход солнечной радиации является негативным фактором.
Экспозиция склона оказывает влияние и на полноту древостоя (табл. 3). Важную роль имеет ориентация склонов в создании запасов фитомассы древесной растительности, которая может быть рассчитана по запасам сырорастущей древесины [3]. Средняя полная биологическая продуктивность наземной части лесных фитоценозов приводится в табл. 3. Наибольшие значения фитомассы обнаруживаются на склонах северных экспозиций (от С3 до СВ), но самые благоприятные условия 
Средняя полнота древостоев на лесных землях по склонам различных экспозиций и на плакоре

\begin{tabular}{|c|c|c|c|c|c|c|c|c|c|}
\hline Экспозиция склона & Плакор & С & СВ & В & ЮВ & Ю & Ю3 & 3 & С3 \\
\hline \multicolumn{10}{|c|}{ Без учета открытых выделов } \\
\hline Полнота & 0,65 & 0,69 & 0,69 & 0,67 & 0,64 & 0,54 & 0,64 & 0,67 & 0,69 \\
\hline \multicolumn{8}{|c|}{ С учетом открытых выделов } \\
\hline Полнота & 0,60 & 0,65 & 0,66 & 0,57 & 0,52 & 0,30 & 0,53 & 0,61 & 0,63 \\
\hline
\end{tabular}

складываются в условиях влажных склонов северо-западных экспозиций (продуктивность фитомассы превышает 210 т/га). Несмотря на больший радиационный баланс склонов южных экспозиций, даже такая сухоустойчивая порода, как дуб имеет запас сырорастущей древесины чуть более $50 \%$ от плакора. Необходимо отметить, что на плакоре, более сухом, чем склоны северных ориентаций, дуб имеет массу наземной части деревьев на 15 т/га больше, чем липа. Это указывает на более комфортные условия для произрастания на плакоре дуба, чем липы. Для липы лучшие условия создаются на склонах северных и северо-западных экспозиций; на склонах южных и юго-восточных экспозиций уступа плато липа практически не встречается. Несмотря на то что объемы древесины у липы больше, чем у дуба, фитомасса липовых лесов меньше, вследствие меньшего удельного веса древесины липы. Отметим, что речь идет о главных склонах уступа плато, а не о склонах отдельных ущелий и оврагов.

Были рассмотрены характеристики растительного покрова не только склонов плато, но и тех оврагов, балок и ущелий, которые врезаются в данные склоны. Для этого было выбрано 5 эрозионных ущелий (оврагов), расположенных на разных склонах Лысогорского плато, и по таксационным описаниям [4] определены ландшафтные характеристики залесенных склонов этих ущелий (оврагов), такие как экспозиция и крутизна склона, формула леса и его характеристики (возраст, полнота, высота и диаметр доминирующей породы, запас сырорастущей древесины). Аналитические материалы представлены в табл. 4, на анализе которой следует остановиться подробнее, так как она является ключом к пониманию особенностей распределения типов лесных сообществ по элементам рельефа.

Таблица 4

Средняя полная биологическая продуктивность наземной части лесных фитоценозов с преобладанием дуба и липы

\begin{tabular}{|c|c|c|c|c|c|c|c|c|c|}
\hline \multirow{2}{*}{ Элементы рельефа } & \multirow{2}{*}{ Плакор } & \multicolumn{8}{|c|}{ Экспозиции склонов } \\
\hline & & $\mathrm{C}$ & $\mathrm{CB}$ & B & ЮB & Ю & Ю3 & 3 & $\mathrm{C} 3$ \\
\hline \multicolumn{10}{|c|}{ Дуб } \\
\hline Фитомасса, ц/га & 2066 & 1839 & 1855 & 1780 & 1487 & 1099 & 1579 & 2171 & 2141 \\
\hline Доля от фитомассы плакора & 1,00 & 0,89 & 0,90 & 0,86 & 0,71 & 0,52 & 0,75 & 1,05 & 1,04 \\
\hline \multicolumn{10}{|c|}{ Липа } \\
\hline Фитомасса, ц/га & 1914 & 2060 & 1988 & 1531 & - & - & 1697 & 1936 & 2143 \\
\hline Доля от фитомассы плакора & 1,00 & 1,08 & 1,04 & 0,80 & - & - & 0,89 & 1,01 & 1,12 \\
\hline
\end{tabular}

Табл. 4 и 5 показывает, что на противоположных склонах ущелья, независимо от того, в какой склон плато оно врезано, фитоценозы резко отличаются. Доминирующей породой на склонах южной ориентации (Ю3, Ю, ЮВ) является дуб, северной ориентации (C3, C, CB) - липа. Даже на, казалось бы, сухих юго-восточных склонах плато, в Смирновском ущелье наблюдается дифференциация пород деревьев по склонам диаметрально противоположных экспозиций.

Наглядным примером служит 73-й лесной квартал, 7-й и 8-й выделы которого расположены на противоположных склонах Октябрьского ущелья. По площади, полноте насаждений, возрасту деревьев эти выделы сходны, однако на северовосточном склоне доминирующей породой является липа (90\% от других видов деревьев), а на юго-западном склоне - дуб (70\%). Соответствен- но, и запасы сырорастущей древесины в первом случае $230 \mathrm{~m}^{3} /$ га, во втором $140 \mathrm{~m}^{3} /$ га.

Склоны северных ориентаций по многим параметрам (видовой состав, полнота насаждений, запас древесины) выгодно отличаются от склонов южных ориентаций. Мы указываем здесь и видовой состав потому, что липа относится к более высокому классу бонитета, нежели дуб (в среднем 3 против 3,85). Такое распределение видового состава по рельефу, скорее всего, связано со степенью увлажнения корнеобитаемого слоя.

Анализ лесотаксационных материалов также показал, что на склонах северных экспозиций чаще встречается подрост из клена и липы разных возрастов (от 5 до 8 лет) с высотой 1,5-3,0 м и густотой от 1,5 до 3 тыс. на га. Склоны южных ориентаций в большинстве своем не имеют развитого подроста. Натурные наблюдения показали, 
Ландшафтные характеристики ущелий (оврагов), врезанных в склоны Лысогорского плато

\begin{tabular}{|c|c|c|c|c|c|c|c|c|c|}
\hline \multirow{3}{*}{$\begin{array}{c}\text { Квартал / } \\
\text { выдел }\end{array}$} & \multirow{3}{*}{$\begin{array}{c}\text { Пло- } \\
\text { щадь, га }\end{array}$} & \multicolumn{8}{|c|}{ Характеристика урочища } \\
\hline & & \multirow{2}{*}{$\begin{array}{c}\text { Экспо- } \\
\text { зиция } \\
\text { склона }\end{array}$} & \multirow{2}{*}{$\begin{array}{l}\text { Крутиз- } \\
\text { на, град }\end{array}$} & \multicolumn{6}{|c|}{ Параметры леса } \\
\hline & & & & Формула леса & $\begin{array}{l}\text { Пол- } \\
\text { нота }\end{array}$ & $\begin{array}{l}\text { Возраст основ- } \\
\text { ной породы, лет }\end{array}$ & $\begin{array}{c}\text { Высо- } \\
\text { та, м }\end{array}$ & $\begin{array}{c}\text { Диаметр, } \\
\text { см }\end{array}$ & $\begin{array}{l}\text { Запас древе- } \\
\text { сины, м³/га }\end{array}$ \\
\hline \multicolumn{10}{|c|}{ Овраг Широкий (северо-западные склоны Лысогорского плато) } \\
\hline $11 / 12$ & 5,7 & Ю & 20 & 10Д & 6 & 65 & 14 & 24 & 130 \\
\hline $11 / 14$ & 0,7 & Ю & 20 & \multicolumn{6}{|c|}{ Открытый участок разнотравно-ковыльной степи } \\
\hline $11 / 15$ & 5,3 & $\mathrm{C}$ & 30 & 5Д3Л & 6 & 100 & 20 & 32 & 180 \\
\hline $12 / 4$ & 4,6 & Ю & 15 & 8Днн2Л & 6 & 40 & 9 & 14 & 60 \\
\hline $12 / 11$ & 4,8 & $\mathrm{C}$ & 5 & 5Д4Лп1Кл & 7 & 90 & 19 & 20 & 180 \\
\hline \multicolumn{10}{|c|}{ Ущелье в р-не горнолыжной базы, 1-я Дачная ост. (восточные склоны Лысогорского плато) } \\
\hline $43 / 1$ & 12,0 & ЮB & 25 & 9Д1Лп & 6 & 45 & 10 & 16 & 70 \\
\hline $43 / 2$ & 3,3 & $\mathrm{C} 3$ & 15 & 8Лп2Ос & 8 & 50 & 11 & 16 & 150 \\
\hline $44 / 6$ & 6,2 & ЮB & 20 & 6Д2Лп2Ос & 6 & 65 & 17 & 24 & 170 \\
\hline $44 / 7$ & 1,7 & $\mathrm{C}$ & 20 & 7Лп3Ос & 8 & 45 & 14 & 16 & 170 \\
\hline $44 / 11$ & 3,5 & $\mathrm{C} 3$ & 20 & 8Лп2Ос & 8 & 45 & 14 & 16 & 170 \\
\hline \multicolumn{10}{|c|}{ Октябрьское ущелье (восточный склон Лысогорского плато) } \\
\hline $73 / 7$ & 2,5 & $\mathrm{CB}$ & 15 & 9Лп1Днв & 8 & 70 & 18 & 20 & 230 \\
\hline $73 / 8$ & 2,8 & Ю3 & 20 & 7Днн3Лп & 6 & 70 & 16 & 22 & 140 \\
\hline $73 / 9$ & 1,9 & Ю & 20 & 8Днн2Лп & 7 & 50 & 13 & 18 & 120 \\
\hline $87 / 2$ & 1,3 & $\mathrm{CB}$ & 25 & 9Лп1д & 8 & 70 & 18 & 20 & 260 \\
\hline $87 / 7$ & 5,1 & $\mathrm{CB}$ & 20 & 8Лп1Днн1Ос & 7 & 60 & 17 & 20 & 190 \\
\hline $74 / 8$ & 2,8 & Ю3 & 20 & 8Д1Лп1Кл & 7 & 45 & 13 & 18 & 130 \\
\hline \multicolumn{10}{|c|}{ Смирновское ущелье (юго-восточные склоны Лысогорского плато) } \\
\hline $90 / 3$ & 1,2 & $\mathrm{CB}$ & 30 & 10Лп+Д+Б+Кл & 5 & 70 & 16 & 20 & 130 \\
\hline $90 / 4$ & 1,0 & Ю3 & 30 & 5Днв4Днн1Кл & 5 & 75 & 18 & 28 & 110 \\
\hline $91 / 3$ & 3,6 & $\mathrm{CB}$ & 45 & 10Лп & 5 & 70 & 16 & 20 & 160 \\
\hline $91 / 8$ & 1,1 & Ю3 & 40 & 8Днн2Лп & 6 & 70 & 14 & 26 & 110 \\
\hline $102 / 1$ & 1,1 & $\mathrm{CB}$ & 35 & 9Лп1Днн & 6 & 60 & 16 & 30 & 170 \\
\hline $102 / 2$ & 0,5 & Ю3 & 30 & 4Днн3Лп2Кл1Ос & 7 & 60 & 17 & 24 & 150 \\
\hline \multicolumn{10}{|c|}{ Овраг Балагой (северо-западный склон Лысогорского плато) } \\
\hline $34 / 5$ & 11,0 & Ю3 & 15 & 8Днн2Лп & 7 & 70 & 15 & 24 & 150 \\
\hline $34 / 11$ & 4,6 & Ю3 & 15 & 8Днн2Лп & 6 & 70 & 15 & 24 & 130 \\
\hline $34 / 12$ & 3,9 & $\mathrm{CB}$ & 10 & 6Лп3Днн1Кл & 7 & 70 & 18 & 22 & 200 \\
\hline $51 / 5$ & 5,4 & $\mathrm{C}$ & 30 & 4Лп4Днн2Кл & 7 & 80 & 20 & 30 & 210 \\
\hline
\end{tabular}

что северные склоны имеют и более мощную лесную подстилку, в то время как на склонах южных ориентаций она в ряде случаев отсутствует.

Что касается оползневых цирков, врезающихся в склоны плато южных экспозиций, то лесные участки расположены чаще всего на верхних крутых частях склонов. Лес здесь представлен практически одними дубами с полнотой $0,4-0,5$, небольшими запасами древесины из-за малого возраста насаждений, скромных параметров древостоя и малой полноты леса.

Показатель продуктивности в виде запаса сырорастущей древесины может служить лишь приблизительным показателем состояния и устойчивости древостоев. В большинстве работ за биологическую продуктивность принимается масса фитомассы, которая может определяться в виде полной (масса органического вещества всей совокупности растений на данном участке) или частичной, когда учитываются отдельные части растений или группы растительности [5]. По данным разных авторов, продуктивность широколиственных лесов в зоне лесостепи может изменяться в очень больших пределах. В районе Борисоглебска Воронежской области запасы фитомассы древесных частей деревьев в дубравах 100-200-летнего 
возраста могут достигать 500-675 т/га, в том числе до 110 т/га корней. Годичная продукция в надземной части древостоев в дубравах варьирует от 5,7 до 7,4 т/га, с максимумом в 43-летнем возрасте. Ясеневые насаждения от 27-до 85-летнего возраста имеют запасы надземной фитомассы в пределах 60-162 т/га, нагорные солонцовые дубравы - в пределах 35-103 т/га (без корней).

В.Д. Утехин [5], ссылаясь на А.А. Молчанова, приводит величину годичной продукции в снытевой дубраве 40-60-летнего возраста, состовляющую около 174 ц/га в абсолютно сухом весе, из которой 25\% приходится на стволовую древесину, 38\% - на корни и только 37\% - на ветви и листву. Он же приводит показатели биологической продуктивности важнейших типов лесостепной фитобиоты: для степной - 235 ц/га (190 ц/га подземная), луговой - 491 ц/га (430 ц/га), лесного травостоя - 191 ц/га (177 ц/га) и для древостоя - 1220 ц/га без определения подземной части. Годичная продуктивность фитоценозов рассчитана по надземной части травостоя. В работе [6] для лесостепи годичная фитопродукция определена величиной 18 ц/га, типичной степи 15 ц/га. В.А. Болдырев [3] приводит следующие данные по запасам органических веществ; для лесов, растущих на супесчаных и суглинистых почвах Саратовского Правобережья от 973 ц/га в дубраве приземистоосоковой до 2032 ц/га в дубраве дубравномятликовой. В липо-дубраве на плакоре запасы органики значительно больше (до 3200 ц/га). В чистых липняках и березняках масса органического вещества составляет от 1450 до

2500 ц/га. Болдырев отмечает, что основная масса органики сосредоточена в древостое и гумусе, масса подстилки варьирует в пределах 5-7\% от общей массы. Масса других компонентов невелика. Как можно видеть, значения самые различные.

На территории лесопарка имеется 590 га непокрытых лесом земель. Среди земель, непокрытых лесом, наиболее привлекательны для отдыха ландшафтные поляны, составляющие 36\% (213 га) от площади этих земель. На таких землях привлекательностью для рекреационной деятельности является травяной покров, который характеризуется составом трав, их густотой (проективным покрытием), наличием или отсутствием дернины, ее состоянием и пр.

Структура травяного покрова в зависимости от условий, которые складываются из особенностей местопроизрастания трав (рельеф, почва и ее увлажнение, тип леса и его полнота и пр.), приводится в табл. 6. Анализируя данные, видно, что типы трав соответствуют лесорастительным условиям, которые довольно разнообразны по элементам рельефа лесопарка: от сухих судубрав $\left(\mathrm{C}_{1}\right)$ до дубрав свежих - влажных $\left(Д_{2-3}\right)$. Разнообразны и типы лесов: в основном дубняки, реже встречаются кленовники, липняки. В сухих и сухих-свежих дубняках преобладают такие виды трав, как мятлик, коротконожка, ландыш, купена лекарственная; встречаются степные виды - ковыль и типчак. С увеличением влажности почвы начинают примешиваться орляк, осока волосистая, сныть, лазурник, сочевник и другие более влаголюбивые виды трав.

Таблииа 6

Распределение структуры травяного покрова и его фитомассы по элементам рельефа парка «Кумысная поляна»

\begin{tabular}{|c|c|c|c|c|c|c|c|}
\hline $\begin{array}{c}\text { Номер } \\
\text { точки }\end{array}$ & $\begin{array}{c}\text { Местполо- } \\
\text { жение (экспо- } \\
\text { зиция) } \\
\end{array}$ & $\begin{array}{c}\text { Квартал/ } \\
\text { выдел }\end{array}$ & $\begin{array}{c}\text { Тип лесора- } \\
\text { стительных } \\
\text { условий }\end{array}$ & $\begin{array}{l}\text { Тип } \\
\text { леса }\end{array}$ & Формула леса & $\begin{array}{c}\text { Доминанты травяного } \\
\text { покрова }\end{array}$ & $\begin{array}{c}\text { Вес травяной } \\
\text { фитомассы, ц/га } \\
\text { (возд. сухой) }\end{array}$ \\
\hline \multicolumn{8}{|c|}{ Трансект № 1 (9-я Дачная остановка, овраг Широкий) } \\
\hline 1 & Плакор & 21,8 & $\mathrm{C}_{1-2}$ & $Д_{б м}$ & 4Д4Л1Б1Кло & $\begin{array}{c}\text { Мятлик дубравный, } \\
\text { ландыш, лазурник, под- } \\
\text { маренник пахучий }\end{array}$ & 4,5 \\
\hline 2 & С склон & 11,15 & $\mathrm{C}_{1-2}$ & $Д_{\text {сн }}$ & 5ДЗЛ2Кло & $\begin{array}{c}\text { Сныть обыкн., мятлик } \\
\text { дубр., фиалка удиви- } \\
\text { тельная, подмаренник } \\
\text { пахучий } \\
\end{array}$ & 4,0 \\
\hline 3 & С склон & 11,15 & $\mathrm{C}_{1-2}$ & - & Открыто & $\begin{array}{c}\text { Горец птичий, пырей } \\
\text { ползучий, одуванчик } \\
\text { лекарст. }\end{array}$ & 9,0 \\
\hline 4 & Ю склон & 11,11 & $\mathrm{C}_{1}$ & - & Открыто & $\begin{array}{c}\text { Ковыль волосатик, по- } \\
\text { лынь, мятлик обыкно- } \\
\text { венный } \\
\end{array}$ & 7,4 \\
\hline 5 & Ю склон & 11,12 & $Д_{1}$ & $Д_{\text {пкл }}$ & 10Д & $\begin{array}{c}\text { Ландыш, подмаренник, } \\
\text { вероника дубр., купена } \\
\text { пахуч. } \\
\end{array}$ & 10,4 \\
\hline \multicolumn{8}{|c|}{ Трансект № 2 (1-я Дачная остановка, северо-восточный склон плато) } \\
\hline 6 & Плакор & 56,2 & $Д_{1}$ & - & Открыто & $\begin{array}{c}\text { Полынь австрийская, } \\
\text { мятлик луговой, пырей } \\
\text { ползучий, чина горохо- } \\
\text { видная } \\
\end{array}$ & 6,2 \\
\hline
\end{tabular}


Продолжение табл. 6.

\begin{tabular}{|c|c|c|c|c|c|c|c|}
\hline $\begin{array}{l}\text { Номер } \\
\text { точки }\end{array}$ & \begin{tabular}{|c|} 
Местполо- \\
жение (экспо- \\
зиция) \\
\end{tabular} & $\begin{array}{c}\text { Квартал/ } \\
\text { выдел }\end{array}$ & $\begin{array}{l}\text { Тип лесора- } \\
\text { стительных } \\
\text { условий } \\
\end{array}$ & $\begin{array}{l}\text { Тип } \\
\text { леса }\end{array}$ & Формула леса & $\begin{array}{c}\text { Доминанты травяного } \\
\text { покрова }\end{array}$ & $\begin{array}{c}\text { Вес травяной } \\
\text { фитомассы, ц/га } \\
\text { (возд. сухой) } \\
\end{array}$ \\
\hline 7 & $\begin{array}{l}\text { СВ склон } \\
\text { верх. ч. }\end{array}$ & 57,7 & $\mathrm{C}_{1}$ & - & 8Л $2 \mathrm{Oc}$ & \begin{tabular}{|c|} 
Мятлик узколиств., осо- \\
ка, лапчатка серебри- \\
стая, клевер альпийск., \\
тысячелистник \\
\end{tabular} & 6,0 \\
\hline 8 & $\begin{array}{l}\text { СВ склон } \\
\text { сред. ч. }\end{array}$ & 57,8 & Д $_{2}$ & - & Открыто & $\begin{array}{c}\text { Мятлик луговой, звезд- } \\
\text { чатка ланцевидн., осо- } \\
\text { ка, клевер альпийск., } \\
\text { костер безостый }\end{array}$ & 7,4 \\
\hline 9 & $\begin{array}{l}\text { СВ склон } \\
\text { сред. ч. }\end{array}$ & 44,12 & $д_{1}$ & - & Открыто & $\begin{array}{c}\text { Пырей ползучий, мят- } \\
\text { лик луговой, одуванчик } \\
\text { лекарст., вероника ду- } \\
\text { шистая } \\
\end{array}$ & 15,1 \\
\hline 10 & $\begin{array}{l}\text { СВ склон } \\
\text { ниж. ч. }\end{array}$ & 44,12 & Д $_{1}$ & - & Открыто & \begin{tabular}{|c|} 
Тысячелистник, лопух, \\
подорожник большой, \\
мятлик узколистн., ло- \\
базник обнаженный \\
\end{tabular} & 29,5 \\
\hline \multicolumn{8}{|c|}{ Трансект № 3 (урочище Корольков сад) } \\
\hline 11 & $\begin{array}{l}\text { ЮЮВ склон } \\
\text { Подножье }\end{array}$ & 117,13 & $\mathrm{C}_{1}$ & - & Открыто & \begin{tabular}{|c|} 
Полынь обыкн., вьюнок \\
полевой, бодяг полевой, \\
подмаренник цепкий, \\
латук татарский
\end{tabular} & 10,0 \\
\hline 12 & $\begin{array}{l}\text { Ю склон } \\
\text { ниж. часть }\end{array}$ & 117,1 & $\mathrm{C}_{1}$ & - & 9Кло1Б & $\begin{array}{l}\text { Сныть обыкн., чисто- } \\
\text { тел, тысячелистник, } \\
\text { вероника дубравная, } \\
\text { мятлик узколистный }\end{array}$ & 12,6 \\
\hline 13 & $\begin{array}{l}\text { Ю склон } \\
\text { сред. ч. }\end{array}$ & 117,5 & $\mathrm{C}_{1}$ & - & Открыто & $\begin{array}{c}\text { Вероника австрийск., } \\
\text { подорожник, костер } \\
\text { береговой, лапчатка } \\
\text { серебр., лютик много- } \\
\text { цветк. }\end{array}$ & 8,8 \\
\hline 14 & $\begin{array}{l}\text { Ю склон } \\
\text { сред. ч. }\end{array}$ & 111,4 & $\mathrm{C}_{1-2}$ & - & Открыто & $\begin{array}{c}\text { Пырей ползучий, горец } \\
\text { птичий }\end{array}$ & 4,4 \\
\hline 15 & $\begin{array}{l}\text { Ю склон } \\
\text { верх. ч. }\end{array}$ & 111,8 & $\mathrm{C}_{1}$ & Д $_{\text {узм }}$ & 4ДЗКлозБ & $\begin{array}{c}\text { Мятлик узколистн., ты- } \\
\text { сячелистник, солодка, } \\
\text { астрагал, Подмаренник, } \\
\text { кирказон обыкновен- } \\
\text { ный }\end{array}$ & 2,0 \\
\hline 16 & Плакор & 111,10 & $\mathrm{C}_{1}$ & $Д_{\text {брм }}$ & 5ДЗБ2Яс & $\begin{array}{c}\text { Мятлик дубр., коровяк, } \\
\text { ковыль волосатик, } \\
\text { клевер }\end{array}$ & 6,3 \\
\hline \multicolumn{8}{|c|}{ Трансект № 4 (плато, оздоровительный лагерь «Дубки») } \\
\hline 17 & Плакор & 82,13 & Д $_{1}$ & Д пкл $_{1}$ & 8Д2Лп & $\begin{array}{c}\text { Ландыш, чистотел, оду- } \\
\text { ванчик лекарств. }\end{array}$ & 10,0 \\
\hline 18 & Плакор & 97,8 & $\mathrm{C}_{1-2}$ & - & $10 \mathrm{C}$ & $\begin{array}{c}\text { Мятлик дубравн., по- } \\
\text { лынь обыкн., гравилат } \\
\text { городской }\end{array}$ & 7,5 \\
\hline 19 & Плакор & 98,7 & $\mathrm{C}_{1-2}$ & - & 5Кло4Д1Лп & $\begin{array}{c}\text { Ландыш, ясменник ду- } \\
\text { шистый }\end{array}$ & 5,6 \\
\hline \multicolumn{8}{|c|}{ Трансект № 5 (западный склон плато, родник «Малиновый») } \\
\hline 20 & ЗСЗ склон & 50,2 & Д $_{1}$ & $Д_{\mathrm{cн}}$ & 6ДЗЛп1Кло & $\begin{array}{l}\text { Сныть, ландыш, фиалка } \\
\text { удивит., купена лекарст. }\end{array}$ & 5,8 \\
\hline 21 & $\begin{array}{l}\text { Тальвег } \\
\text { балки }\end{array}$ & 49,9 & Д $_{2-3}$ & - & 4Кло5Ол1Лп & $\begin{array}{c}\text { Сныть, ландыш, мятлик } \\
\text { лесной, звездчатка лан- } \\
\text { цетная }\end{array}$ & 4,6 \\
\hline
\end{tabular}


Окончание табл. 6.

\begin{tabular}{|c|c|c|c|c|c|c|c|}
\hline $\begin{array}{c}\text { Номер } \\
\text { точки }\end{array}$ & $\begin{array}{l}\text { Местполо- } \\
\text { жение (экспо- } \\
\text { зиция) }\end{array}$ & $\begin{array}{c}\text { Квартал/ } \\
\text { выдел }\end{array}$ & $\begin{array}{l}\text { Тип лесора- } \\
\text { стительных } \\
\text { условий }\end{array}$ & $\begin{array}{l}\text { Тип } \\
\text { леса }\end{array}$ & Формула леса & $\begin{array}{c}\text { Доминанты травяного } \\
\text { покрова }\end{array}$ & $\begin{array}{c}\text { Вес травяной } \\
\text { фитомассы, ц/га } \\
\text { (возд. сухой) }\end{array}$ \\
\hline 22 & $\begin{array}{c}\text { Тальвег бал- } \\
\text { ки }\end{array}$ & 48,10 & $Д_{2}$ & - & 7Лп2Д1Кло & $\begin{array}{c}\text { Ландыш, осока, звезд- } \\
\text { чатка, сныть, крапива } \\
\text { двудомная }\end{array}$ & 5,9 \\
\hline \multicolumn{8}{|c|}{ Трансект № 6 (плато, Большая Кумысная поляна - район урочища Лаптев сад) } \\
\hline 23 & Плакор & 23,9 & $Д_{2}$ & - & Редина & $\begin{array}{c}\text { Полынь горькая, под- } \\
\text { маренник, клевер, тыся- } \\
\text { челистник }\end{array}$ & 9,8 \\
\hline 24 & Плакор & 23,4 & $Д_{2-3}$ & $Д_{\mathrm{cн}}$ & 7Д2Кло1Лп & $\begin{array}{l}\text { Сныть обыкновенная, } \\
\text { шалфей, мятлик лесной }\end{array}$ & 10,2 \\
\hline 25 & Плакор & 38,8 & Д $_{2}$ & - & $10 Б$ & $\begin{array}{l}\text { Мятлик лесной, лапчат- } \\
\text { ка, полынь, клевер }\end{array}$ & 11,6 \\
\hline 26 & Плакор & 38,6 & $Д_{1}$ & $Д_{\text {пкм }}$ & 7Д2Лп1Б & Осока, ландыш, клевер & 9,0 \\
\hline 27 & Плакор & 52,7 & $\mathrm{C}_{1}$ & - & $10 \mathrm{C}$ & $\begin{array}{c}\text { Мертвопокровный, из } \\
\text { кустарников рябина }\end{array}$ & - \\
\hline \multicolumn{8}{|c|}{ Трансект № 7 (северный склон с выходом на водораздел: 5-я Дачная остановка - район Савельевских гор) } \\
\hline 28 & $\begin{array}{l}\text { С склон } \\
\text { сред. ч. }\end{array}$ & 1,5 & $\mathrm{C}_{1-2}$ & - & 9Лп1Кло+Д & $\begin{array}{c}\text { Ясменник, чистотел, } \\
\text { купена лекарств., гра- } \\
\text { вилат городской, осока, } \\
\text { мятлик узколистный }\end{array}$ & 7,8 \\
\hline 29 & Плакор & 6,6 & $\mathrm{C}_{1}$ & $Д_{\text {узм }}$ & 5Д4Лп1Кло & $\begin{array}{c}\text { Мятлик узколистный, } \\
\text { вероника дубравная, } \\
\text { таволга }\end{array}$ & 8,2 \\
\hline 30 & Бровка плак. & 13,1 & $\mathrm{C}_{1}$ & $Д_{\text {узм }}$ & 5Кло4Д1Б & $\begin{array}{c}\text { Купена лекарст, лан- } \\
\text { дыш, ясменник (под- } \\
\text { стилка до } 2 \text { мм) }\end{array}$ & 10,0 \\
\hline 31 & $\begin{array}{l}\text { Ю склон } \\
\text { балки }\end{array}$ & 14,6 & $\mathrm{C}_{1-2}$ & Д $_{\text {бм }}$ & 4Д4Лп2Кло & $\begin{array}{c}\text { Звездчатка, лазурник } \\
\text { трехлопастной, купена } \\
\text { лекарст., мятлик ду- } \\
\text { бравный } \\
\end{array}$ & 12,6 \\
\hline 32 & Плакор & 24,4 & $\mathrm{C}_{1-2}$ & - & $100 \mathrm{c}+$ Лп & $\begin{array}{c}\text { Ясменник, купена ле- } \\
\text { карст., мятлик дубрав- } \\
\text { ный } \\
\end{array}$ & 9,9 \\
\hline 33 & Плакор & 24,8 & $Д_{2}$ & - & 6Ос3Лп1Д+К & $\begin{array}{c}\text { Мятлик лесной, лапчат- } \\
\text { ка, осока }\end{array}$ & 9,2 \\
\hline 34 & Бровка плак. & 41,1 & $\mathrm{C}_{1-2}$ & $Д_{\text {бм }}$ & 5Д5Лп+Ос & $\begin{array}{c}\text { Мятлик дубравный, } \\
\text { коротконожка, ландыш, } \\
\text { купена лек. }\end{array}$ & 10,1 \\
\hline
\end{tabular}

Натурные исследования запасов фитомассы, которые производились в начале июля 2008 г., показали значительный разброс ее показателей по территории (от мертвопокровной поверхности до 29,5 ц/га в сухо-воздушном состоянии). В целом на открытых участках запас фитомассы трав в основном определялся увлажнением почвенного слоя, в лесу увеличение влажности не всегда приводило к росту веса фитомассы. В этом отношении показателен трансект, проходящий в районе «Малинового родника», где, несмотря на значительную влажность почвы, вес фитомассы не вышел за пределы 6 ц/га, что связано с высокой степенью сомкнутости древостоя $(0,8-0,9)$. Аномально высокая продуктивность травяного покрова зафиксирована в месте выхода родников (точка $10)$ в районе 1-й Дачной остановки (29,5 ц/га), причем видовой состав представлен влаголюбивыми типами - лопухом, подорожником, бодягом и др.
Наименьшая продуктивность трав наблюдается в оползневом цирке на юго-восточных склонах плато (2-4 ц/га на верхних крутых участках склона), лишь на нижних участках и у подножья продуктивность составила 10-12 ц/га.

Наблюдения показали, что на склонах плато южных и юго-восточных экспозиций степная растительность высоко поднимается к водоразделу и прибровочные части плакора здесь начинают приобретать остепненный характер. Даже на лесных участках наблюдается появление злаковой дернины.

Несмотря на малое число выделов, для которых рассчитывалась продуктивность фитомассы травяного покрова, можно заметить некоторые закономерности в распределении ее веса по элементам рельефа. На плакоре открытые участки в среднем имеют большую фитомассу по сравнению с лесными участками (9,3 и 7,5 ц/га), на бровках плакора так- 
же увеличивается продуктивность трав (10,4 ц/га), на склонах происходит рост запаса фитомассы с уменьшением высоты. Тальвеги ущелий, за счет большой полноты древостоя, обладают сравнительно малой продуктивностью трав.

Построенные карты параметров фитоценозов могут служить материалом для оценки состояния лесных кварталов с экологической точки зрения, которую можно назвать степенью экологического неравновесия, или устойчивости экосистем. Для этого на одну ландшафтную основу необходимо наложить все параметры, которые можно принять в качестве индикаторов состояния фитоценозов. Нами в качестве степени неравновесия были выбраны средние показатели по лесотаксационным кварталам: объем стволовой древесины менее 110 м³/га, возраст древостоев менее 60 лет, доля открытых участков более $50 \%$, полнота древостоя менее 0,5 и густота дорожно-тропинчатой сети более 0,09 км/га. Каждый из них указывает на ранимость геосистемы, а в комплексе они указывают на значительную дигрессию участков, на которых рекреационная деятельность должна быть ограничена. При этом степень ограниченности должна возрастать с числом неблагоприятных факторов в лесном квартале.

Все параметры определенного порога, выбранные для оценки экологического состояния, наносятся с карт разных показателей на единую карту, затем производится анализ. Наиболее ранимыми являются кварталы, расположенные на юго-восточном и восточном склонах уступа - кварталы 88 и 112, менее ранимыми - 111 и 113, что видно из рис. 2. Число

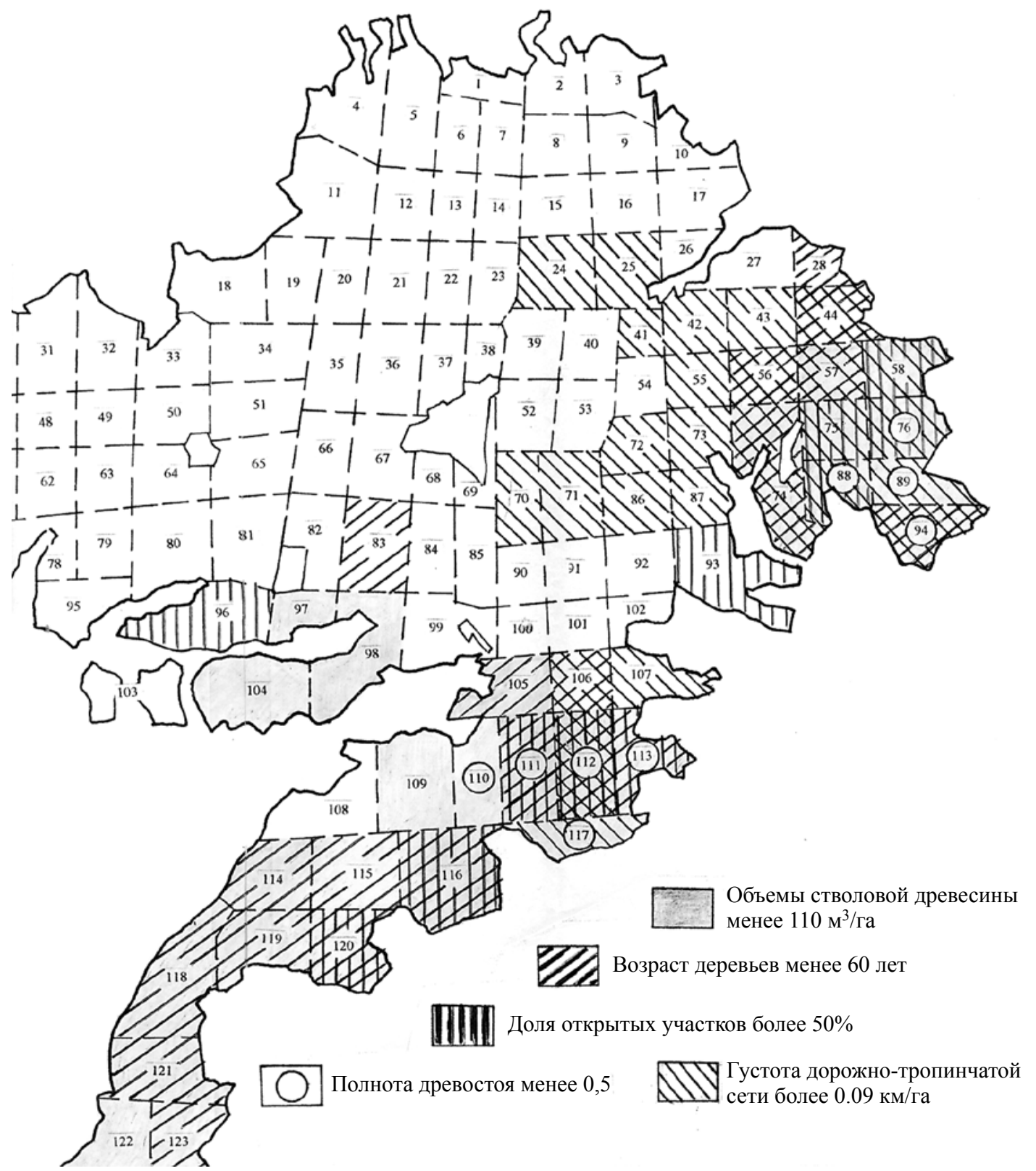

Рис. 2. Схема степени экологической неустойчивости в лесных кварталах лесопарка «Кумысная поляна». 
совпадений неблагоприятных факторов в них максимально (равно 5) и относительно велико (равно 4). Подобный анализ степени устойчивости лесных фитоценозов проведен по лесотаксационным кварталам, но это можно сделать и по лесотаксационным выделам.

Таким образом, гео- и биогеофизические показатели состояния реально отражают дифференциацию ландшафтных условий, вскрывают причинно-следственные связи, причем геофизические показатели структуры ландшафта выступают как причины, биогеофизические - как следствие. Экологическая значимость этих показателей также велика, вследствие чего они вполне могут служить методологической основой при оценке ландшафтной структуры региона.

\section{Библиографический список}

1.Трифонова Т.М. Лесные насаждения в Саратове на эродированных склонах Лысой горы // Сб. науч. тр. Сарат. сельскохоз. ин-та. Саратов, 1983. С. 62-73.

2. Викторов А.С. Рисунок ландшафта. М.: Мысль, 1986. $178 \mathrm{c}$.

3. Болдырев В.А. Естественные леса Саратовского Правобережья: Эколого-ценотический очерк. Саратов: Изд-во Сарат. ун-та, 2005. 92 с.

4. Проект организации и развития лесного хозяйства леспаркхоза «Кумысная поляна»: В 3 т. Т. 1. Объяснительная записка. Воронеж, 1995. $185 \mathrm{c}$.

5. Утехин В.Д. Первичная биологическая продуктивность лесостепных экосистем. М.: Наука, 1977. 147 с.

6. Дьяконов К.Н. Геофизические показатели функционирования ландшафтов для оценки антропогенных воздействий // Вестн. Моск. ун-та. Сер. 5, География. 2003. № 1. С. $15-19$.

\section{УДК 551.590 .2}

\section{ПЕРИОДИЧЕСКИЕ ИЗМЕНЕНИЯ АТМОСФЕРНОГО ДАВЛЕНИЯ, ВЫЗВАННЫЕ ВЛИЯНИЕМ КОСМИЧЕСКИХ ФАКТОРОВ}

\section{М.Б. Богданов, А.В. Федоренко}

Саратовский государственный университет, кафедра метеорологии и климатологии E-mail: BogdanovMB@info.sgu.ru

Проведен анализ спектра мощности временного ряда ежедневных значений атмосферного давления, измеряемых альпийской высокогорной станции Юнгфрауйох с 1968 по 1992 г. В спектре ряда обнаружены гармоника полюсного прилива, вызываемого движением полюса Земли, две гармоники лунно-солнечного прилива, гармоника с периодом синодического месяца, вызванная изменением инсоляции при движении системы Земля - Луна вокруг общего центра масс, а также две гармоники, проявляющиеся в изменениях межпланетного магнитного поля, существование которых объясняется особенностями механизма солнечного динамо.

Ключевые слова: атмосферное давление, спектр мощности, гармоники, приливы, инсоляция, солнечная активность.

\section{Periodical Changes in the Atmospheric Pressure, Caused by the Influence of the Space Factors}

\section{M.B. Bogdanov, A.V. Fedorenko}

We carried out the analysis of the power spectrum of the time series of the daily values of the atmospheric pressure measured in high-level Alpine station Jungfraujoch in the time interval from 1968 through 1992. In the power spectrum are discovered the harmonic of polar tide, caused by the Earth's pole motion, two harmonics of luni-solar tide, the harmonic with the period of synodic month, connected with a change in the insolation during the motion of system the Earth - Moon around the common center of masses, and also two harmonics revealed in changes in the interplanetary magnetic field,

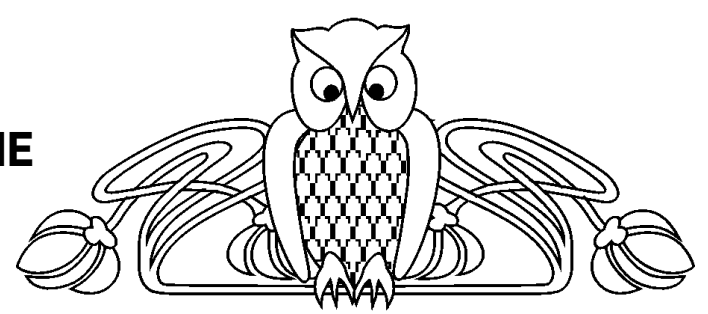

whose existence is explained by the features of the solar dynamo mechanism.

Key words: atmospheric pressure, power spectrum, harmonics, tides, insolation, solar activity.

\section{Введение}

Изучение проблемы влияния космических факторов на процессы, протекающие в глубинах нашей планеты, ее атмосфере и гидросфере представляет большой интерес для многих наук о Земле. В число этих факторов входят разнообразные проявления солнечной активности [1], особенности движения Земли в Солнечной системе, ее вращения вокруг собственной оси и движение полюса $[2,3]$, а также приливные воздействия Луны и Солнца, способные вызывать изменения океанической циркуляции и влиять на характеристики регионального и глобального климата [4-6]. Степень влияния некоторых факторов сравнительно невелика. Однако периодический характер воздействия позволяет надеяться обнаружить его проявление при анализе достаточно продолжительных временных рядов геофизических величин.

В ходе предыдущих исследований мы изучили изменения приземной температуры воздуха и обнаружили наличие ряда гармоник, возникающих под влиянием космических факторов $[7,8]$. Целью настоящей работы является поиск возможных периодических составляющих, связанных 